Van der Schee, J., Notté, H., Zwartjes, L. (2010). Some thought about a new international geography test. International Research in Geographical and Environmental Education, Vol. 19 (4): 277-282.

\title{
Some thoughts about a new International Geography Test
}

\author{
Joop van der Schee \\ VU University, Amsterdam, The Netherlands
}

\author{
Henk Notté \\ Cito, Arnhem, The Netherlands
}

Luc Zwartjes

Vereniging Leraars Aardrijkskunde, Belgium

An important question for geography teachers all over the world is how to define, stimulate and test geographical literacy. Although modern technology is no guarantee of quality, it offers new possibilities for teaching and testing, as can be seen in contemporary geography learning/teaching units using digital maps and interactive tests. The Charter of the IGU Commission on Geographical Education and tests such as the International Geography Olympiad can be starting points for an international discussion about the quality of geography teaching and for the development of a new international geography test.

Key words: geography tests, geography Olympiad, geographical literacy.

\section{The Charter of the Commission on Geographical Education}

The International Charter on Geographical Education of the Commission on Geographical Education of the International Geographical Union (Haubrich, 1994; IGU-CGE, 2006) is an important statement that supports geographical education all over the world. It includes the geographical core content, key concepts and statements about the importance and organisation of geography teaching. It is an useful guide to develop a national geography curriculum and a framework for geography teaching methods and geography tests. The Charter proved to be especially useful in countries where people wanted to develop or change a geography curriculum. The working-out of the Charter will be different in every country dependent on the national or regional context. Purnell (1994) suggested developing an international item bank based upon the International Charter on Geographical Education from which countries could choose and develop their own test.

Niemz and Stoltman (1992) developed the InterGeo II test, a project of the Commission on Geographical Education of the International Geographical Union. InterGeo II was administered in 1990 and 1991. The main objectives were to assess student achievement in geography, to assist in the development of world class standards in geography and to provide data that some countries might use to help improve geography curricula (Purnell, 1994). The project included a reliable test for making cross-national comparisons of achievement in geography for 14-year-old students. More than 13,500 students from 23 countries participated in the test. The data analyses 
suggested a wide variation in basic geographical achievement between the students. The average scores of students in the former socialist countries of Eastern Europe were higher than the scores of students elsewhere. The test results helped the national coordinators to detect deficiencies in subfields of geography and to improve the national geography curricula, teaching methods and geography tests.

\section{The International Geography Olympiad}

The first International Mathematical Olympiad for upper secondary students started in 1959 in Romania.Under auspices of the , the first International Geography Olympiad started in 1996 in the Netherlands. The first International Geography Olympiad Most of the themes of the iGeo tests have counterparts in the list of themes mentioned in an issues based approach in the Charter (see Figure 1). Issues such as crisis regions and conflicts are missing from the list for the Olympiad. Themes such as climate change, landscapes, transport and tourism are not mentioned in the list of current issues and problems in the Charter. These differences will give rise to a reconsideration of both lists. 


\begin{tabular}{|l|l|}
\hline International Geography Olympiad & Charter on Geographical Education \\
\hline 1. climate \& climate change & \\
\hline 2. hazards \& hazard management & - hazards and disasters \\
\hline 3. resources \& resource management & - energy management \\
\hline $\begin{array}{l}\text { 4. environmental issues \& sustainable } \\
\text { development }\end{array}$ & $\begin{array}{l}\text { - environmental quality } \\
\text { - sustainable development }\end{array}$ \\
\hline 5. land forms, landscapes \& land use & \\
\hline 6. population \& population change & $\begin{array}{l}\text { - population dynamics } \\
\text { - inequalities in race, gender or religion }\end{array}$ \\
\hline $\begin{array}{l}\text { 7. economic geography \& globalisation } \\
\text { 8. transport, infrastructure \& logistics } \\
\text { management }\end{array}$ & $\begin{array}{l}\text { - global change } \\
\text { - limits to growth }\end{array}$ \\
\hline $\begin{array}{l}\text { 9. urban geography, urban renewal \& urban } \\
\text { planning }\end{array}$ & - development problems and strategies \\
\hline 10. agricultural geography \& food problems & - hunger in the world \\
\hline 11. tourism \& tourism management & \\
\hline 12. regions \& regional identities & - socio-spatial disparities \\
\hline & $\begin{array}{l}\text { - crisis regions } \\
\text { - conflict }\end{array}$ \\
\hline
\end{tabular}

Figure 1. Themes of the International Geography Olympiad tests compared with themes in an issues based approach in the Charter on Geographical Education (Haubrich, 1994). 

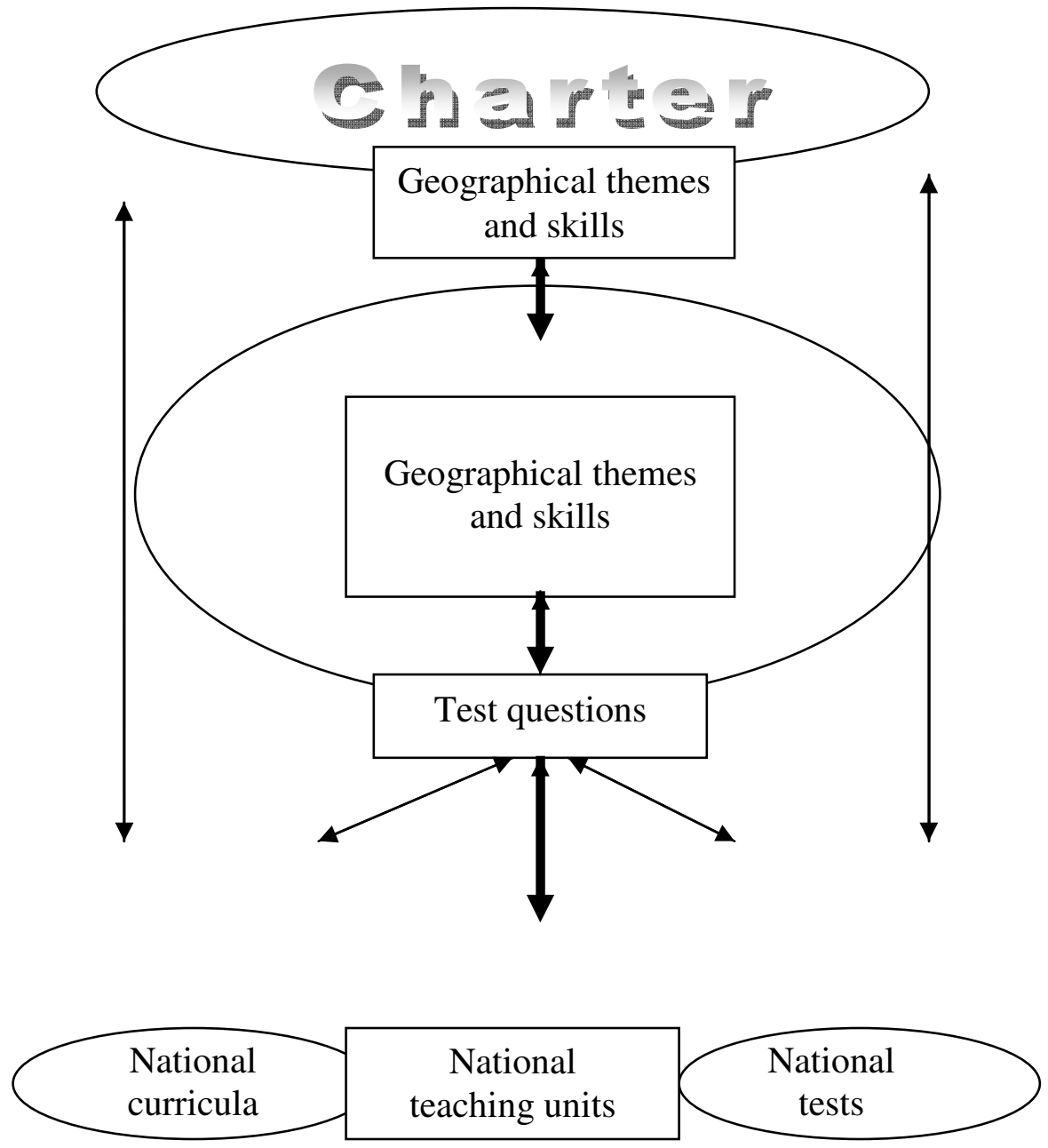

Figure 2. The relationship between the Charter, Olympiad and the national level

Figure 2 shows the relationship between the Charter, the iGeo and the national curricula, teaching units and tests. Documented evidence of the impact of national and international Geography Olympiads on the national level is scarce. Wilczynska-Woloszyn (1992) who was one of the three founders of the International Geography Olympiad in 1994, wrote about the effect of the National Geography Olympiad on geography teaching in Poland. Geography Olympiads including fieldwork have been held in Poland since 1974. In the beginning Polish teachers did not accept the tests of the Olympiad because they were used to examinations in which the reproduction of facts dominated, but later the situation changed. Geography handbooks in Poland written after 1974 show clearly the influence of the National Geography Olympiads. More recently Liiber and Roosaare (2007) report impacts of the Olympiads on national curricula and 
teaching units. They write that the Olympiads have a direct and an indirect influence on both curriculum development and teaching methods in Estonia:

"Many tasks from the Olympiad are used in classroom work to diversify the teachinglearning process. Therefore, the geography Olympiad is a development engine not only for teachers but also for school geography in general".

\section{The International Geography Olympiad (iGeo)}

More countries than ever participated in the 2008 iGeo in Tunisia: Australia, Belarus, Belgium, China-Beijing, China-Taipei, Czech Republic, Estonia, Finland, Germany, Hungary, Japan, Latvia, Lithuania, Mexico, The Netherlands, New Zealand, Poland, Romania, Russia, Saudi Arabia, Slovakia, Slovenia, Tunisia and the United Kingdom. In The Hague twelve years ago only six countries participated in the International Geography Olympiad. Each of the 24 participating countries in Tunisia consisted of a team of four secondary school students, aged 1619, and two adult team leaders. The students were selected through a national competition. The Olympiad consisted of three parts: a written response test (40\% of total marks), a substantial fieldwork exercise (40\%), and a multimedia test (20\%). One of the first questions of the multimedia test of the 2008 iGeo was:

Here are three photographs. They were all taken in the same country. Look carefully. In which country were they taken?
A Kuwait
B Gambia
C Yemen
D Turkey

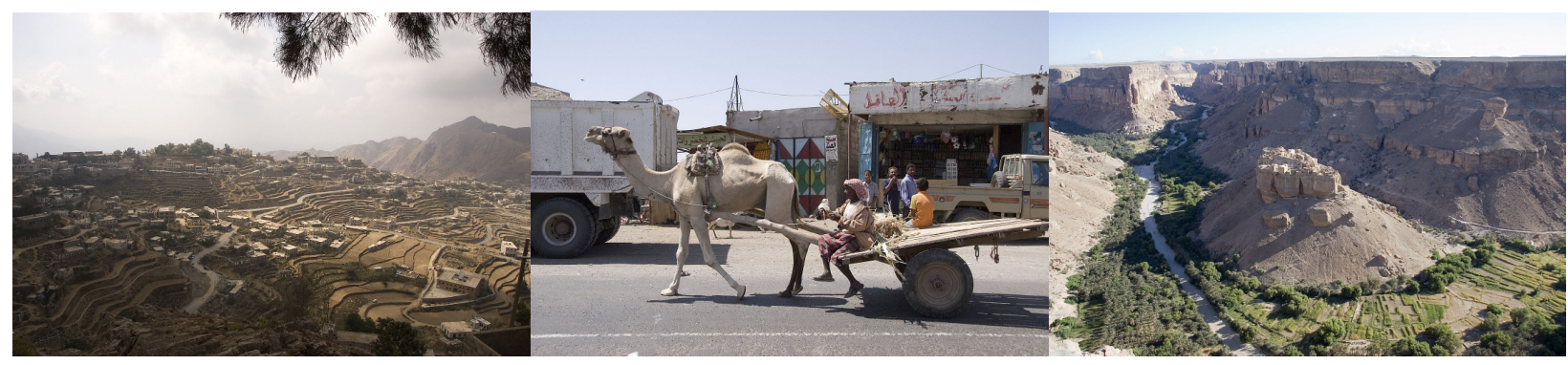

(photographs: Irene de Groot)

To give the right answer students need to have a lot of geographical knowledge. Students must know where the countries are on the globe, and must have knowledge about the distribution of mountains, street life and landscapes in different regions of the world. As this question illustrates, the multimedia test of the iGeo transcends the mere knowledge of facts and figures. Geography is more than knowing place names. It is about frontiers, centres and peripheries; about tourists, terrorists and refugees; about trade of food, drugs and digital data; about population growth, earthquakes and the distribution of diseases like SARS. Contemporary geography is about understanding the world we live in by studying spatial patterns and processes and how they work out in different parts of the world. Geography is much more significant than most people realize. Geographers focus on world themes like globalization and sustainable development and study 
these themes in a special way by looking at locations, distributions and interaction. All this is vital to understand everyday life on our globe. The iGeo is a good opportunity to show what geographers can contribute. It can help to change the vague, outdated images many people have of geography (Ostuni, 2003).

\section{The GEA experience}

With the advent of multi-media computer resources, geography has the opportunity to exploit its comparative advantage as a field of study where visuals in particular provide the raw material for learning. Virtual reality will make geography instruction come even more alive in the near future (Miller and Zeigler, 1994). The extended visual and technical possibilities can also be used in geography tests.

Notté and Van der Schee (2008) describe the development of a national Dutch computer-based geography test. The GEA test is a trip around the world, constructed as an interactive game in which GEA is the name of a travelling companion during the test. Starting in The Netherlands, the participant travels East through 18 zones each of 20 degrees of longitude. As in games the etest has levels. There are five levels: for players younger than 10 year old, 10-12 year-olds, 1315 year-olds, 16-18 year-olds and players of 18 year old or more. The test is adaptive and everybody starts at level three. If an answer is correct, the next question will be at a higher level and if an answer is not correct the next question will be at a lower level. From a test bank with approximately 400 questions the programme selects a question for the player's current geographical zone and that fits their geographical level. To answer the question correctly the traveller needs geographical knowledge about locations, landscapes and population characteristics, all being indispensable luggage for a global citizen on his or her way around the earth. Immediately after the test the participants are informed of their geographical expertise. In 2007 more than 2000 visitors to a geography exhibition completed the test. The average "travel" time was 7 minutes and 45 seconds. The results showed that most of the participants younger than 16 years-old played in the first three levels. Most 16-18 year-olds attained level four and the highest average scores were found in the group of 18 plus. However, within the group of adults scores did not rise with age, so there was no proof of the often heard lamentation that younger people miss the solid geographical knowledge of elderly people. The Dutch GEA test will be revised, retested and re-used in 2008 and 2009 and a web based version will be ready in 2010 to assess the geographical expertise of students from 10 to 18 years of age. To make an English version of this school-type independent test is a small step. The multimedia test questions of the International Geography Olympiad shown at the start of this paper can also be used in GEA. The difference between the Olympiad tests and the GEA test is that the latter is a big geography test item bank as suggested by Purnell (1994) and can also be used for diagnostic purposes.

\section{Discussion}

An international version of GEA should be a recent development that extends the InterGeo tests and the International Geography Olympiad tests. These activities are the building blocks of a new interactive and international geography test. Although some geographers may not see the value of such tests, we think that a new test can be a reference point for geographers in education worldwide to think about the content and the process of geography teaching. The pressure to 
cover the prescribed curriculum content and to prepare students for examination often limits the teacher's flexibility to do more than geography teaching itself. Developing an international geography test will be helpful for all those involved in geography teaching. It will be interesting to determine what shared geographical knowledge and skills could be reasonably expected of an international population, starting from what has been formulated in the Charter on Geographical Education. Computer technology enables us to make this geography test much more sophisticated than the old fact and figures tests. The technology can be used to enrich tests by using an interactive and adaptive test structure. It also offers the opportunity to combine different sources such as digital maps, photos and video simultaneously or successively.

The theoretical underpinnings for the structure of such a test are derived from Stimpson (1992). With the use of modern test analysis methods (Verhelst, Glas and Verstralen, 1995) the answers to different versions of a test can be compared and reliable statements on the level of geography literacy in different countries can be made. In addition, there is the prospect of comparative research using scores in the existing international tests like the International Geography Olympiad. Is there a difference between students from different parts of the world if we compare their scores on the written response test, the multimedia test and the fieldwork exercises and what is the relationship between these scores and geography teaching in different countries? Is the difference between knowledge and skills an important one or it is the difference between human and physical geography? How do successful Olympiad participants - most of the winning teams come from Eastern Europe - train? What are their knowledge and skills before they enter the tests?

In many countries the position of geography in education is under threat. At the same time we see that geographical themes like climate change, energy supplies, sustainable development and globalization dominate the news. What we need is a benchmark for geographical literacy, based on an international test, that may help to draw more attention to the importance of geography and good geography teaching. Such an approach would be even more effective if it was combined with research not so much in the field of assessment of learning but in the field of assessment for learning.

Assessing students' geographical progress is an important point in the educational process. The next important step is to help them adequately think through geography. Research in this field is scarce (Van der Schee, Leat and Vankan, 2006). School curricula in many countries present a lot of facts and concepts to the students, but a systematic training in acquiring and using geographical knowledge and skills in practically-oriented assignments is another story. Geography's assessment for learning should have its benchmark in international tests that combine the knowledge and skills that are related to the contemporary issues on planet earth of today and tomorrow.

\section{Correspondence}

Any correspondence should be directed to prof. dr. Joop van der Schee, Onderwijscentrum VU, VU University, De Boelelaan 1105, 1081 HV Amsterdam, The Netherlands

(j.vanderschee@ond.vu.nl). 


\section{References}

Haubrich, H. (1994) International Charter on Geographical Education. Nürnberg: IGU-CGE / Hochschulverband für Geographie und ihre Didaktik.

IGU-CGE (2006), Revision International Charter on Geographical Education, http://igucge.tamu.edu/charters_1.htm, accessed 25/06/2008.

Miller, G. E. \& Zeigler, D. (1994) Geo-technology and geography teaching. In H. Haubrich (ed.) Europe and the world in Geography Education. Nürnberg: IGU-CGE / Hochschulverband für Geographie und ihre Didaktik, 353-363.

Niemz, G. \& Stoltman, J. (1992) Distractor Analysis of InterGeo II Items: A Way to Improve Geographical Curricula. In A. D. Hill (ed.) Interdependence in Geographic Education.

Proceedings IGU-CGE. Boulder: University of Colorado, 161-165.

Notté, H. \& Schee, J. van der (2008) De wereld rond met Gea. Geografie, 17 (2), 40-41.

Liiber, U. \& Roosaare, J. (2007) Geography Olympiads in Estonia. International Research in Geographical and Environmental Education, 16 (3), 293-298.

Ostuni, J. (2003) Geography and the community. In: R. Gerber (Ed) International Handbook on Geographical Education. Dordrecht: Kluwer Academic Publishers, 75-85.

Purnell, K.N. (1994) International testing in geography: The InterGeo project. In H. Haubrich (ed.) Europe and the world in Geography Education. Nürnberg: IGU-CGE / Hochschulverband für Geographie und ihre Didaktik, 155-160.

Stimpson, Ph. (1992) Assessment in geography: an evaluation of the SOLO taxonomy. In H. Schrettenbrunner \& J. van Westrhenen (eds.) Empirical Research and Geography Teaching. Amsterdam: VU University, 157-175.

Van der Schee, J., Leat, D. \& Vankan, L. (2006) Effects of the Use of Thinking Through Geography Strategies. International Research in Geographical and Environmental Education, 15 (2), 124-133

Verhelst, N. D., Glas, C. A.W. \& Verstralen, H. H. F. M. (1995) One parameter logistic model (OPLM). Arnhem: CITO. 
Wilczynska-Woloszyn, M. (1992) Geography Education and Geography Olympiad. In A. D. Hill (ed.) Interdependence in Geographic Education. Proceedings IGU-CGE. Boulder: University of Colorado, 245. 